Editorial

\title{
Muslim Mobilities and Gender: An Introduction
}

\author{
Viola Thimm \\ Asien-Afrika-Institut (Asia-Africa-Institute), Department of Languages and Cultures of Southeast Asia, \\ University of Hamburg, Edmund-Siemers-Allee 1, 20146 Hamburg, Germany; viola.thimm@uni-hamburg.de; \\ Tel.: +49-40-428-387-537
}

Received: 21 December 2017; Accepted: 25 December 2017; Published: 28 December 2017

\section{Mobilities}

Mobility represents the common imagination that the current world is in a constant flux, based on, for example, technical development, wide arrays of infrastructure and digital communication (Fábos and Isotalo 2014). The mobile world is constituted through mobile people, objects, narratives, symbols and representations. The common notion is that the world is more mobile than it has ever been before. This understanding approaches mobility with positively attributed meanings, which are based on capitalist and neoliberal discourses: Increasing mobility inheres the ability and freedom to move and the possibility of flexible changes (e.g., Endres et al. 2016a; Uteng and Cresswell 2008). This approach to mobility focuses on transformations of mobile practices, rather than on representations and negotiations linked to mobility and is highly contested (Endres et al. 2016b, p. 2).

The myriad current dynamics of flows of people and their ideas and goods are studied with either a theoretical or empirical mobility approach. Regarding the first strand, using mobility as a concept can be a way of understanding the mobile lives of people (e.g., Endres et al. 2016a; Uteng and Cresswell 2008; Hannam et al. 2006). In this sense, mobility is a lens to research this field with a certain optic and, therewith, ordering it accordingly. The latter strand investigates the diverse kinds of movements by, for example, migrants, refugees, tourists, pilgrims, international students, journalists, NGO personnel and diplomats. This approach has been extended to include research dealing with walking, travelling by train or even electric flows into mobility studies. As part of this approach, John Urry differentiates mobilities as follows:

1. Corporeal travel of people for work, leisure, family life, pleasure, migration and escape; 2. Physical movement of objects delivered to producers, consumers and retailers; 3. Imaginative travel elsewhere through images of places and people on television; 4 . Virtual travel often in real time on the internet, so transcending geographical and social distance; 5. Communicative travel through person-to-person messages via letters, telephone, fax and mobile phone (Urry 2004, p. 28, as quoted in (Uteng and Cresswell 2008, p. 1); emphasis in original).

People have always been mobile, which means that on the descriptive level, mobility is not a new phenomenon. However, the scholarly attention and analytical approach has developed only relatively recently. Many academic centers (e.g., the Scalabrini Institute for Human Mobility in Africa (SIHMA), Cape Town; the European Center for Sustainable Mobility, University of Applied Sciences Aachen; the New Mobilities Research and Policy Center; Drexel University), journals (e.g., Mobilities, Transfers, Applied Mobilities) and conferences (e.g., Nexus of Migration and Tourism: Creating Social Sustainability, ATLAS Asia-Pacific Conference 2018; AAG 2018: Expanding the debate on transport and mobility justice; (Im)mobility: Dialectics of Movement, Power and Resistance, LSE 2018; Inaugural Conference of "Laboratory of City and Mobility": "Arquitectura entre escalas y la ciudad Latinoamericana," Universidad Católica de Chile 2017) focus on mobility which, as a whole, has institutionalized this field of study. Researching social phenomena through the lens of movement-either theoretically or 
empirically framed-emerged as the new mobilities paradigm or mobility turn across multiple disciplines, such as anthropology, geography, history, sociology or transportation research (Hannam et al. 2006), as a response to the (assumed) increase of flows of people and objects.

The distinctiveness of mobility studies is not the additive subsumption of various forms of movement under one roof but that it captures the connections between human mobility, technology and transportation and, therewith, brings technical development, infrastructure, objects and human movement together. The understanding of entanglements of movements of people, objects and symbols

[transcends] the dichotomy between transport research and social research, putting social relations into travel and connecting different forms of transport with complex patterns of social experience conducted through communications at a distance (Endres et al. 2016a, p. 1).

Hence, the inclusiveness of the category of mobility opens up the possibility of connecting movement, sedentarism and transportation analytically. Dynamics, for example, in the field of Muslim pilgrimage, such as the higher number of pilgrims, emerging Muslim middle classes in many regions which can afford such journeys and transformations of pilgrimage practices which include more and more consumption activities, can be better understood when taking the development of the corresponding infrastructure, i.e., from ship to airplane, from limited carriers to a wide range of possible routes, into account (Thimm 2017).

Approaching mobility with this lens clearly shows that the common understanding of an increasingly mobile world has its limitations. Not only do the infrastructural and technical possibilities play a crucial role for understanding mobile ways of people but also the embeddedness of these possibilities into power structures, which equally stop people from being mobile or never enable people to move, is another. Focusing power relations regarding mobility leads to the other side of the coin: immobility (e.g., Gutekunst et al. 2016; Glick Schiller and Salazar 2013). Glick Schiller and Salazar (2013) conceptualize mobility in their article "Regimes of Mobility Across the Globe," as a form of physical movement which is contingent on socio-structural constraints, which are an expression of power. They frame mobility as being part of power regimes and, thereby, understand human movement as embedded within sociopolitical, historical and economic relationships. The ability to move based on people's resources and, therewith, on their social position are bound directly to the immobility of other groups of people who cannot refer to such resources and structures. Mobility/mobilization and sedentarism or immobility/immobilization are often not two binary poles but interrelated states for the same people (Götz 2016, p. 10). This understanding marks a turn from a binary, dichotomous understanding of mobility/immobility to a relational one, which emphasizes power constellations and the ways they operate on a discursive level. Using im/mobility as a term of complexity, recognizes power regimes as framings of the connections between human movement and sedentarism. Refugees, for example, cannot cross space and especially borders easily. Their physical movement is slow and limited through their way of transportation, i.e., on foot, hidden in trucks and trains, or in perilous rubber dinghies and depends on segregations by nationality, regional and cultural origin as they are classified by powerful governments in the Western World. The resulting segregation is a decision regarding who gets quickly deported by plane and who can stay, some for a short while only but some other ones forever (e.g., Vigneswaran and Quirk 2015; Ashutosh and Mountz 2012). Governing of movement and institutional control of human movements are fundamental parts of mobility. Including these powerful regulations of mobility into the common understanding challenges the neoliberal notion of the constantly increasing mobility of people, ideas and objects.

Being sensitive of power hierarchies when it comes to movement or to the counterpart-the exclusion from movement-brings us to an understanding that power is an inherent part of mobility. Considering that walking, driving or virtual mobility is equally subsumed under the umbrella term "mobilities" by many scholars (e.g., Papon and Flonneau 2017; Faulconbridge 2015; Kesselring and Clarke 2013), the socio-cultural and political complexity demonstrates that not every form of movement is automatically mobility but needs to fulfill particular criteria. Noel Salazar suggests the following important differentiation between movement and mobility: 
Analytically speaking, movements (as brute acts of motion) become mobilities when they gain meaning as experienced and imagined socio-cultural assemblages. People are moving all the time but not all movements are equally meaningful and life-shaping (both for those who move and those who stay put) (Salazar 2016b, p. 285).

Sara Bonfanti (Bonfanti 2016, p. 185) enhances Salazar's approach by bringing in two additional aspects for a conceptualization of mobilities: "[M]obility [is] constituted not only by movement but also by meaning or ideological representations and by power, be it economic, symbolic or political".

Following Salazar's and Bonfanti's understandings, mobility is movement which acquires meaning through the social actors involved. This meaning-making process is embedded in the power relations in which they interact, however, these power relations are influenced by the mobility of people. In this sense, mobility is not only a form of movement measured empirically but also a form of representation and embodiment.

This approach understands mobility as an analytical category, rather than a descriptive term. It requires an analysis of which movements can be grasped as mobility and why. Working with the concept of mobility, hence, is a way of ordering social phenomena as objects scholars deal with, on the one hand and of ordering research, on the other. Mobility is "as an ever-changing object of knowledge co-shaped and co-constituted by social sciences" (Endres et al. 2016b, p. 3, emphasis in original). This means that the way scholars systematize and order social phenomena is the reason why the mobility paradigm emerged, not the analyzation of descriptive facts.

Mobility studies deal with the manifold ways in which people get involved in transregional, transnational or global networks, or how they are excluded from them and how people and objects cross time and space (Salazar 2016a, p. 3; Sheller and Urry 2016, p. 12). Hence, this field of investigation, furthermore, entails the category of space. Spaces are constituted through social relations and social action (Schroer 2006; Löw 2001; Werlen 1987). The meaning of places and the spatiality of conditions are constituted in relation to and as a result of activities simultaneously (Werlen 2010, p. 63). Social spaces are, in turn, bound to materiality and lived in geographical places (Werlen 2005). The socio-spatial relationships reflect territorially based mechanisms of appropriation and allocations of different discourses. Hence, space is a place of social order, which brings us back to the aspect of power as part of mobility.

Through using space as an analytical tool, discourses, practices and aspirations become issues of globality. Human movements are better analyzed and understood with and not in contrast to other types of movements, considering not only human movements but also the massive flows of capital and goods which are, simultaneously, an expression, trigger and result of globalization. The global space reminds us that social debates and practices are not locally split but transcend regional and national borders and boundaries. This space between different regions or nation states arises from mobile subjects passing through it, which can be related to each other socially. The linkages between the categories of space and globalization, furthermore, have changed conceptualizations of space: Processes of globalization, which become evident in new information technology and infrastructure, induce "time-space-compression" (Harvey 1989), hence, spatial and temporal overlaps and entanglements. New perceptions of geographical distances and social relationships, which people have over such distances, are constantly developing. Social relationships can by now be maintained over hundreds to thousands of kilometers. Through telecommunications and the World Wide Web, hurdles of time difference and geographical distance are reduced with one click in the Internet.

\section{Muslim Mobilities and Gender}

Mobility as a lens bridges human mobility and transportation and analyzes these entanglements in their embeddedness in meaning-making and power hierarchies. Structural factors, such as sociopolitical and economic circumstances and backgrounds, play huge roles when it comes to questions such as who can be mobile at which particular historical time and why. With its specification of "Muslim" mobilities (see Fábos and Isotalo 2014), this special issue deals with the im/mobile lives 
of Muslims, especially regarding the religious or spiritual backgrounds to, influences of and reasons or motivations for their im/mobility. Dealing with this field, we should differentiate between religion and spirituality. The religious side relates to practices based on religious guiding principles or obligations such as going on pilgrimage. People do not only go on hajj (pilgrimage) or umrah ("small pilgrimage") for religious purposes but also for spiritual motivations, which is getting closer to Allah or losing one's ego, for example. Both sides, the religious and the spiritual, form the motivation of Muslims to be mobile. Performing hajj or umrah due to religious obligations and spiritual enhancement leads to further spatial ordering of the Muslim world, which encourages many Muslims to migrate or visit other Islamic places or regions with a high Muslim and Islamic influence. The idea of a "Muslim center" and of a "Muslim periphery" is crucial for the orientation of Muslims in an imagined Muslim world. Exemplarily, Mecca in today's Saudi Arabia is regarded as the center of the Muslim world (Abaza 2011) by most Muslims, as the Kaaba-the black cube in Mecca which symbolizes the house of God (baitullah) - is believed to be located at the center of the world. Muslims from all over the world visit these sites for their pilgrimage; 300-330 million pilgrims currently perform their religious obligations at the key sites on the Arab Peninsular every year (Vukonić 2010, p. 33). Based on this concept of sacred regions, Muslims in Asia, Africa or Latin America are positioned and position themselves on the margins of these regions. The ordering based on spiritual reasons becomes evident when considering the numerical side: Indonesia has the world's largest Muslim population but is regarded as part of the "Muslim periphery" (see (Lücking and Eliyanah 2017) in this issue).

Religion is not only a theological or institutional expression of certain imaginations and ideologies but a specific interpretation of social reality and, therewith, a socio-cultural approach to the world (Sand1kc1 and Jafari 2013; Schielke 2010). This specific interpretation of reality gets its expressions in institutions (organizations), traditions (oral and material traditions such as symbols, songs, scriptures) and social practices (prayers, moral behavior). Religion offers a comprehensive worldview and, therewith, produces and projects meaning, forms identities, offers orientation for daily activities and legitimizes or delegitimizes power. This special issue deals with these different approaches to Islam and Muslim ways of life: On the one hand, it deals with the sense of "religion," which has its roots, in a Western way of thinking, as an understanding of a human relation to (a) divine being(s). On the level of social processes, this understanding is especially related to institutions and institutional power. On the other hand, it deals with Muslim notions of religion which can be better grasped by the concept of din. From a Muslim perspective, din includes the obligations Allah imposes on humans, i.e., rational beings. Din is the mutual obligation between Allah and Allah's followers, who submit to Allah's authority (Sand1kc1 and Jafari 2013, p. 412). This concept includes the way of living, the mental, spiritual and intellectual attitude and the behavior and practices an individual or society follow. It comprises the whole human life in its fullness.

Understanding Islam as a complex net of meaning-making (not only for the im/mobile lives of people), it is, furthermore, a cultural practice entangled with other categories of difference. According to this understanding, Islam as a religion and a way of seeing the world is interwoven with, among other things, gender. Regarding religion and gender as axes of differentiation means focusing them as social constructs that have inflected the varied and unequal lives of people throughout the world for generations. Religion and gender express identifications which are mutually constitutive and inform how people interact with one another. "Identifications" are personal and collective senses of belonging which are culturally constituted, embedded in sociopolitical and historical conditions and, therewith, not anything naturally given (Brubaker and Cooper 2000). The term "identification" extends the static notion of "identity" by adding a perception of dynamic social relations. In this regard, this special issue deals with the intersections of Muslim mobilities and gender (see Uteng and Cresswell 2008), in the sense of negotiating belonging, identity and relations between women, men and other genders based on the respective identifications as a woman, a man or a transgender, for example.

In their entangled effectiveness, religion and gender influence the degree to which people can be mobile (see, e.g., Werbner 2015; Falah and Nagel 2005). The analytical approach to understanding 
mobility in this respect is popularly termed the "intersectionality" framework (e.g., Thimm et al. 2017; Phoenix and Pattynama 2006; Hooks 2000; Crenshaw 1989). This framework, stemming from the black feminist movements in the US, has become a useful tool for analyzing linkages between social locations, identities and social power structures. Religion could be the only lens applied to analyses of people's im/mobile lives. It is useful to engage with other axes of differentiation, such as gender-but it can be race, ethnicity, class, or sexual orientation, to understand the complexity and richness of social processes. In other words, to analyze how religion interacts with gender and one another and how, in turn, this influences mobility or sedentarism.

It is this understanding that provided the inspiration for this special issue. The aim has been to analyze social relations, identifications and power in im/mobility when it is rooted in religious and/or gendered backgrounds and social structures by bringing together scholars from different disciplines and regional contexts who are interested in engaging in a dialogue between Islamic concepts, Muslim practices and gender and mobility theories. The articles illustrate complex, multiple and even contradictory perspectives on the connections between Islam, gender and mobility. For this special issue, I was particularly interested in works that incorporate historical and sociopolitical understandings into the analysis of the realities of Muslim "movers." Research that employs interdisciplinary investigations of contemporary gender orders, norms and practices in this regard, as part of a net of social relations organizing power and inequality, were particularly welcome. Consequently, I invited contributions that explore the multiple and complex ways that religion, gender and mobility inform and are informed by one another in the call for this special issue. I hope that the articles will accomplish this aim and inspire further research on religion-gender-mobility intersections especially and encourage a critical, situated and dynamic engagement with identities and power hierarchies in order to advance mobility theory in general.

\section{Contributions in This Issue}

The composition of the articles of this special issue show the variety of how Muslim mobility and gender can be studied as dynamic social fields, on the one hand (Byng 2017; Giuliani et al. 2017; in this issue). On the other hand, it provides insight into the possibilities of using it as theoretical lens to investigate the respective other fields: Mobility can be used as a theoretical lens (and, therewith, as an inclusive category, see (Kramer 2017) in this issue) to investigate gender (Daoud 2017; Golkowska 2017; in this issue). A theoretical gender optic (Lücking and Eliyanah 2017; Shanneik 2017; Wagner 2017; in this issue) or a more complex theoretical approach, i.e., intersectionality, can be used as a lens to approach im/mobility (McLean and Higgins-Opitz 2017; Bianchi 2017; Amin 2017; in this issue).

The first section of this special issue, Moving through Different Gendered Spaces, shows what being mobile in everyday life can mean to mobile people themselves and how they navigate through different spaces. In this section, "movement" is key for understanding relations between different social spaces and, therewith, serves as an analytical tool for understanding the connections between gendered spaces. Suheir Abu Oksa Daoud (Daoud 2017) analyzes connections between space, place and identity in general and how transportation (driving cars) relates to space and gender especially in her article Negotiating Space: The Construction of a New Spatial Identity for Palestinian Muslim Women in Israel (Daoud 2017). Using in-depth interviews, Daoud examines the impact of space on Muslim Palestinian women living in ethnically divided cities and how ethnicity and patriarchy make a difference in shaping their spatial experiences. Muslim women in Israel have not usually been very present in spaces outside their homes or villages but they have engaged in new spaces in economic, social and educational fields. One strategy for challenging limitations in the public realm is driving private cars, as this "opens new spaces for women and increases women's freedom, confidence, independence, mobilization and involvement in the public space," Daoud argues. The author, therewith, introduces this special mode of transportation to the investigation of women's mobility. In the second article of this section, Qatari Women Navigating Gendered Space (Golkowska 2017), Krystyna Golkowska challenges conventional understandings of gendered spaces by examining Qatari women's agency within existing 
frameworks of the gender-space nexus. Referring to data gathered from the literature as well as ethnographic observation and shared narratives, the author reveals a significant increase in women's presence in the public sphere based on moving into traditionally male dominated spaces, such as education, employment and sports and, thereby, gaining visibility and agency within these spaces.

Whereas the articles in the first section deal with gendered spaces within one nation state, the next section of this issue, Creating and Negotiating a Transnational Muslim Space, analyzes the reverse: Firstly, this section deals with a global or transnational space, i.e., the analysis goes beyond one nation state and secondly, the authors do not focus on how this space is gendered but rather "religionized," as I want to put it, based on shared Islamic beliefs and practices. The articles in this section investigate formations of transnational religious space with a theoretical gender approach. Mirjam Lücking and Evi Eliyanah deal with different forms of mobility (pilgrimage, labor migration) in their article Images of Authentic Muslim Selves: Gendered Moralities and Constructions of Arab Others in Contemporary Indonesia (Lücking and Eliyanah 2017) and with transnational engagements and negotiations with global discourses in the Muslim World and how these intersect with notions of morality. Based on ethnographic research in Indonesia and a cultural analysis of cinematic representations of Indonesian students in Cairo, the authors examine how Indonesian Muslims, who have traveled to or lived in Western Asia or Northern Africa, define and negotiate their identifications in relation to Arab others. This process takes place against the backdrop of imaginations of a "Muslim Center" (the Arab World) and "Periphery" (the other Muslim majority regions of the world). Within this global sphere of Muslim localizations, gendered moralities-as conceptions of what constitutes good Muslim men and women-are central to images of authentic Muslim selves, Lücking and Eliyanah argue. In the next article of this section, Shia Marriage Practices: Karbala as lieux de mémoire in London, Yafa Shanneik deals with diaspora and migration, conceptualized in a transnational or global field, as she researches engagements with ideas and practices in the Shia Muslim world (Shanneik 2017). Shanneik shows how Iraqi Shia women in the UK contest and negotiate identity and belonging by referencing to places and spaces that relate to their identity and self. Hence, these identity negotiations in a transnational field become possible based on the past mobile lives of the social actors. The author conceptualizes the transnational aspects of cultural memory expressed in Shia marriage practices as examples of transnational Shia lieux de mémoire (which refer to spaces, objects or events that have a significant meaning to a particular group's collective memory as theorized by Pierre Nora). She investigates how marriage rituals, images and objects are used by Iraqi Shia women as a means to preserve religious and cultural memory simultaneously and challenge existing marriage practices. Shanneik enhances Nora's concept by bringing in the transnational as the field of identity-making. The third article of this section, Mattering Moralities: Learning Corporeal Modesty through Muslim Diasporic Clothing Practices by Lauren B. Wagner, examines how gendered Muslim corporeality (through clothing practices) is negotiated in a transnational field by constantly physically mobile European-Moroccans (Wagner 2017). The author researches how moral bodies materialize with and through clothing by observing and following the constant mobilities of social actors who are moving back and forth across spaces dominated by "Muslim" and "Western" "regimes of modesty and morality," as Wagner puts it. She investigates particularly how modesty is constructed and constituted through Muslim Moroccan women's bodies across transnational spaces and argues that bodies, clothes and gazes are entangled agents which produce modesty in the transnational field.

The third section of this special issue, From Mobility to Immobility: Intersectional Identifications as Opportunities or Limitations, deals with mobility's counterpart: immobility, based on power hierarchies. The interplay of mobility and immobility functions here as a field of investigation. The authors in this section examine the $\mathrm{im} /$ mobility nexus with a theoretical gender or intersectionality optic. This is similar to the approach in the previous section Creating and Negotiating a Transnational Muslim Space but the fields of mobility and gender are extended in this section by immobility and intersectionality. Michelle McLean and Susan B. Higgins-Opitz (2017) examine gender as a limitation for physical and social mobility (the latter in the form of professional careers) in their article Male and Female Emirati 
Medical Clerks' Perceptions of the Impact of Gender and Mobility on Their Professional Careers (McLean and Higgins-Opitz 2017). The authors analyze the "feminization," i.e., the increase in the number of women, of medicine by investigating how gender influences the career of medical students in the United Arab Emirates based on semi-structured interviews. McLean and Higgins-Opitz argue that gender intersects with mobility at the point of the student's opportunities, as these are limited for female students based on travel restrictions in the context of a patriarchal, gender-segregated but rapidly changing society in the Gulf. Despite having aspirations and opportunities of specializing abroad, most of the female final year medical students did not take the chance because of the fact or assumption that this would not be possible, as they either need a chaperone or the permission to travel granted by their fathers, brothers or husbands. As more women take up studies in medicine and practice their profession successfully, the young women in McLean's and Higgins-Opitz's study are actors in the field of a changing profession and challenge gender-related values of their broader society, the authors argue. In the next article of this section, Reimagining the Hajj (Bianchi 2017), Robert R. Bianchi deals with Muslims who are on the move for religious reasons (hajj and umrah pilgrimage) and how they encounter limits and boundaries in this mobile phase. The author analyzes death rolls made public by whistle blowers in the Saudi Ministry of Health in 2016: The data accessed reveals details about pilgrim deaths in Mecca from 2002 to 2015 (90,276 victims from more than 100 countries), such as the names, nationalities, genders, ages and dates of death. Bianchi reveals that the most vulnerable pilgrim populations are poor people, women and children from across Africa and Asia, as well as foreign workers, refugees and illegal migrants living in Saudi Arabia. In the sense of an intersectionality informed lens, he shows how gender intersects with class, for example. Whereas Muslim pilgrims from affluent societies, such as the Gulf countries, benefit from ongoing medical attention, indigent pilgrims from Mali, Mauritania, Myanmar and Yemen have difficulty helping themselves. Bianchi proposes to reform and reinvent the hajj by lengthening the hajj season from five days to several months to improve the situation drastically. In the third article of this section, Gender, Madness, Religion and Iranian-American Identity: Observations on a 2006 Murder Trial in Williamsport, Pennsylvania (Amin 2017), Camron Michael Amin takes "regimes of mobility" and the mobility-immobility nexus as a lens to study intersectional interwoven dynamics. In his microhistorical case study, he deals with the intersection of ethnicity, religion and gender in constructing the social identity of Iranian-Americans. Amin uses particularly Iranian-American/diaspora Studies and im/mobility (regimes of mobility) as an approach to study the case of Brian Hosayn Yasipour, who was sentenced for murdering his daughter. The author argues that the judgment "transformed [Brian Hosayn Yasipour] ( . . ) from an Iranian immigrant, who was free to move between Iranian/Muslim and (White) American/Christian contexts, into an American murderer who was confined to prison" (Amin 2017, p. 2). Therewith, he shows clearly how intersectionally embedded perspectives and circumstances influence social positioning, expressed in possibilities and limitations of individuals.

The next section of this issue, Intersecting Forms of Im/mobility, investigates gender through a mobility lens. Hence, the approach in this section is contrary to the investigation of mobility with a gender lens in both sections Moving through Different Gendered Spaces and From Mobility to Immobility: Intersectional Identifications as Opportunities or Limitations. Max Kramer deals with the interplay of mobility and immobility and with different forms of mobility in Mobilizing Conflict Testimony: A Lens of Mobility for the Study of Documentary Practices in the Kashmir Conflict (Kramer 2017) and savors the inclusiveness of the category of mobility. He applies a lens of mobility to the study of documentary film practices and gender in zones of conflict (Kashmir, Northern India) by carrying out ethnographic research. Kramer argues that different mobilities intersect in the filmic practices of filmmaker Iffat Fatima, who discusses representation of Kashmiri Muslim women's agency in conflict zones: When the filmmaker travels with her film and screens it at various places, the audiences get emotionally and intellectually mobilized through the experience of watching it and debating about its subject (Kramer 2017). Against the backdrop of representations of Muslim women in conflict zones as 
(religiously) immobilized victims, the filmmaker Fatima challenges this narrative by showing female subjects in their everyday (im-)mobility and their participation in demands for political autonomy.

The last section of this issue, entitled Moving and Settling: Identity Negotiations in Muslim Migration Contexts, deals with forms of mobility, in this case, with the special form of migration which serves as the field of investigation here. Michelle Byng works on transnational migration from various Muslim majorities countries to the West and how this form of movement is informed by intersectionality in Transnationalism among Second-Generation Muslim Americans: Being and Belonging in Their Transnational Social Field (Byng 2017). Using qualitative interview data, the author investigates what experiences second generation Muslim Americans face when visiting their parents' country of origin and how this influences their perceptions of their US American identity. On the macro level, the national and global conflicts around Islam raise important questions about the citizenship of Muslims in the West. On the micro-level, being an American is central to the identity of second-generation Muslims in the United States, which is shaped predominantly by debates and practices regarding religion, ethnicity and nationality within their transnational social field, Byng argues. The second article in this section, Being a "Good" Son and a "Good" Daughter: Voices of Muslim Immigrant Adolescents by Cristina Giuliani, Maria Giulia Olivari and Sara Alfieri (Giuliani et al. 2017), similarly studies migration from Muslim majority countries (Morocco, Egypt and Pakistan) to the West (Italy). In contrast to Byng's study on second generation Muslims, this article considers the case of immigrant adolescent children who moved to Italy through family reunification. The authors examine how notions of morality (being a "good" son and a "good" daughter) intersect with gender. They argue that being obedient and respectful of parents' desires is differently articulated by Muslim immigrant girls and boys. Girls must and do focus themselves on staying at home and preserving heritage culture, whereas boys emphasize the importance of educational success to develop the possibility of becoming the breadwinner in their own prospective families. The authors clearly point out that their respondent's post-migration experience is highly influenced by identity negotiations based on the cultural and social expectations of their migrant parents and host country.

Apparently, these four sections are meant to be a starting point for the comparative analysis of the phenomenon in question but they do not cover the entangled processes of Muslim mobilities and gender in its entirety. The present special issue of Social Sciences intends to give a first in-depth analysis which, it is hoped, will be complemented and expanded by future research.

Acknowledgments: I am grateful to the editorial team of Social Sciences for taking care of the publication of this special issue. Managing Editor Siyang Liu supported the whole process with valuable assistance. I would also like to thank the anonymous peer reviewers who took their time to review the manuscripts. They made a generous and valuable contribution and helped to improve the quality of the special issue as a whole.

Conflicts of Interest: The author declares no conflict of interest.

\section{References}

Abaza, Mona. 2011. Asia Imagined by the Arabs. In Islamic Studies and Islamic Education in Contemporary Southeast Asia. Edited by Kamaruzzaman Bustamam-Ahmad and Patrick Jory. Kuala Lumpur: Yayasan Ilmuwan, pp. 1-28.

Amin, Camron Michael. 2017. Gender, Madness, Religion, and Iranian-American Identity: Observations on a 2006 Murder Trial in Williamsport, Pennsylvania. Social Sciences 6: 85. [CrossRef]

Ashutosh, Ishan, and Alison Mountz. 2012. The Geopolitics of Migrant Mobility: Tracing State Relations through Refugee Claims, Boats and Discourses. Geopolitics 17: 335-54. [CrossRef]

Bianchi, Robert R. 2017. Reimagining the Hajj. Social Sciences 6: 36. [CrossRef]

Bonfanti, Sara. 2016. Dislocating Punjabiyat: Gendered Mobilities among Indian Diasporas in Italy. In Bounded Mobilities: Ethnographic Perspectives on Social Hierarchies and Global Inequalities. Edited by Miriam Gutekunst, Andreas Hackl, Sabina Leoncini, Julia Sophia Schwarz and Irene Götz. Bielefeld: Transcript, pp. 183-205.

Brubaker, Rogers, and Frederick Cooper. 2000. Beyond 'Identity'. Theory and Society 29: 1-47. [CrossRef] 
Byng, Michelle. 2017. Transnationalism among Second-Generation Muslim Americans: Being and Belonging in Their Transnational Social Field. Social Sciences 6: 131. [CrossRef]

Crenshaw, Kimberlé. 1989. Demarginalizing the Intersection of Race and Sex: A Black Feminist Critique of Antidiscrimination Doctrine, Feminist Theory and Antiracist Politics. University of Chicago Legal Forum 140: 139-67.

Daoud, Suheir Abu Oksa. 2017. Negotiating Space: The Construction of a New Spatial Identity for Palestinian Muslim Women in Israel. Social Sciences 6: 72. [CrossRef]

Marcel Endres, Katharina Manderscheid, and Christophe Mincke, eds. 2016a. The Mobilities Paradigm: Discourses and Ideologies. London and New York: Routledge.

Marcel Endres, Katharina Manderscheid, and Christophe Mincke, eds. 2016b. Discourses and Ideologies of mobility: An Introduction. In The Mobilities Paradigm: Discourses and Ideologies. London: Routledge, pp. 1-7.

Fábos, Anita H., and Riina Isotalo. 2014. Introduction: Managing Muslim Mobilities: A conceptual Framework. In Managing Muslim Mobilities: Between Spiritual Geographies and the Global Security Regime. Edited by Anita H. Fábos and Riina Isotalo. New York: Palgrave Macmillan, pp. 1-18.

Falah, Ghazi-Walid, and Caroline Nagel. 2005. Geographies of Muslim Women: Gender, Religion, Space. New York: Guilford Publications.

Faulconbridge, James. 2015. Changing practices: A key role for temporality and spatiatlity-James Faulconbridge. Mobile Lives Forum. October 28. Available online: http:/ / en.forumviesmobiles.org/video/ 2015/10/28/changing-practices-key-role-temporality-and-spatiatlity-james-faulconbridge-2958 (accessed on 17 December 2017).

Giuliani, Cristina, Maria Giulia Olivari, and Sara Alfieri. 2017. Being a "Good" Son and a "Good" Daughter: Voices of Muslim Immigrant Adolescents. Social Sciences 6: 142. [CrossRef]

Glick Schiller, Nina, and Noel B. Salazar. 2013. Regimes of Mobility across the Globe. Journal of Ethnic and Migration Studies 39: 183-200. [CrossRef]

Götz, Irene. 2016. Mobility and Immobility: Background of the Project. In Bounded Mobilities: Ethnographic Perspectives on Social Hierarchies and Global Inequalities. Edited by Miriam Gutekunst, Andreas Hackl, Sabina Leoncini, Julia Sophia Schwarz and Irene Götz. Bielefeld: Transcript, pp. 9-11.

Golkowska, Krystyna. 2017. Qatari Women Navigating Gendered Space. Social Sciences 6: 123. [CrossRef]

Miriam Gutekunst, Andreas Hackl, Sabina Leoncini, Julia Sophia Schwarz, and Irene Götz, eds. 2016. Bounded Mobilities: Ethnographic Perspectives on Social Hierarchies and Global Inequalities. Bielefeld: Transcript.

Hannam, Kevin, Mimi Sheller, and John Urry. 2006. Editorial: Mobilities, Immobilities and Moorings. Mobilities 1: 1-22. [CrossRef]

Harvey, David. 1989. The Condition of Postmodernity. An Enquiry into the Origins of Cultural Change. Oxford: Blackwell.

Hooks, Bell. 2000. Feminist Theory: From Margin to Center. London: Pluto Press.

Kesselring, Sven, and Elly Clarke. 2013. On the Move: In the Virtual and the Physical Worlds. Mobile Lives Forum. March 1. Available online: http://en.forumviesmobiles.org/crossed-perspectives/2013/03/01/ move-virtual-and-physical-worlds-611 (accessed on 17 December 2017).

Kramer, Max. 2017. Mobilizing Conflict Testimony: A Lens of Mobility for the Study of Documentary Practices in the Kashmir Conflict. Social Sciences 6: 88. [CrossRef]

Löw, Martina. 2001. Raumsoziologie. Frankfurt am Main: Suhrkamp.

Lücking, Mirjam, and Evi Eliyanah. 2017. Images of Authentic Muslim Selves: Gendered Moralities and Constructions of Arab Others in Contemporary Indonesia. Social Sciences 6: 103. [CrossRef]

McLean, Michelle, and Susan B. Higgins-Opitz. 2017. Male and Female Emirati Medical Clerks' Perceptions of the Impact of Gender and Mobility on Their Professional Careers. Social Sciences 6: 109. [CrossRef]

Papon, Francis, and Mathieu Flonneau. 2017. The future of cars: Triumph or decline? Mobile Lives Forum. January 13. Available online: http:/ / en.forumviesmobiles.org/arguing/2017/01/13/future-cars-triumphor-decline-3411 (accessed on 17 December 2017).

Phoenix, Ann, and Pamela Pattynama. 2006. Intersectionality. European Journal of Women's Studies 13: 187-92. [CrossRef]

Salazar, Noel. 2016a. Keywords of Mobility: What's in a Name? In Keywords of Mobility: Critical Engagements. Edited by Noel B. Salazar and Kiran Jayaram. New York: Berghahn, pp. 1-12. 
Salazar, Noel. 2016b. Conceptual Notes on the Freedom of Movement and Bounded Mobilities. In Bounded Mobilities: Ethnographic Perspectives on Social Hierarchies and Global Inequalities. Edited by Miriam Gutekunst, Andreas Hackl, Sabina Leoncini, Julia Sophia Schwarz and Irene Götz. Bielefeld: Transcript, pp. 284-89.

Sandıkcı, Özlem, and Aliakbar Jafari. 2013. Islamic encounters in consumption and marketing. Marketing Theory 13: 411-20. [CrossRef]

Schielke, Samuli. 2010. Second Thoughts about the Anthropology of Islam, or How to Make Sense of Grand Schemes in Everyday Life. ZMO Working Papers 2010; Berlin: ZMO.

Schroer, Markus. 2006. Räume, Orte, Grenzen: Auf Dem Weg zu Einer Soziologie des Raums. Frankfurt am Main: Suhrkamp. Shanneik, Yafa. 2017. Shia Marriage Practices: Karbala as lieux de mémoire in London. Social Sciences 6: 100. [CrossRef]

Sheller, Mimi, and John Urry. 2016. Mobilizing the New Mobilities Paradigm. Applied Mobilities 1: 10-25. [CrossRef]

Thimm, Viola, Mayurakshi Chaudhuri, and Sarah J. Mahler. 2017. Enhancing intersectional analyses with polyvocality: Making and illustrating the model. Social Sciences 6: 37. [CrossRef]

Thimm, Viola. 2017. Commercialising Islam in Malaysia: Ziarah at the intersection of Muslim pilgrimage and the market-driven tourism industry. In Siri Kertas Kajian Etnik UKM (UKM Ethnic Studies Paper Series Bil. 56. Bangi: Institut Kajian Etnik, Universiti Kebangsaan Malaysia.

Uteng, Tanu Priya, and Tim Cresswell. 2008. Gendered Mobilities: Towards an Holistic Understanding. In Gendered Mobilities. Edited by Tanu Priya Uteng and Tim Cresswell. Aldershot: Ashgate, pp. 1-12.

Darshan Vigneswaran, and Joel Quirk, eds. 2015. Mobility Makes States: Migration and Power in Africa. Philadelphia: University of Pennsylvania Press.

Vukonić, Boris. 2010. Do We always Understand Each Other? In Tourism in the Muslim World. Edited by Noel Scott and Jafar Jafari. Bingley: Emerald, pp. 31-45.

Wagner, Lauren B. 2017. Mattering Moralities: Learning Corporeal Modesty through Muslim Diasporic Clothing Practices. Social Sciences 6: 97. [CrossRef]

Werbner, Pnina. 2015. Sacrifice, Purification and Gender in the Hajj. In Hajj: Global Interactions through Pilgrimage. Edited by Luitgard Mols and Marjo Buitelaar. Leiden: Sidestone, pp. 27-39.

Werlen, Benno. 1987. Gesellschaft, Handlung und Raum: Grundlagen Handlungstheoretischer Sozialgeographie. Stuttgart: Steiner. Werlen, Benno. 2005. Raus aus dem Container: Ein sozialgeografischer Blick auf die aktuelle (Sozial-)Raumdiskussion. In Grenzen des Sozialraums: Kritik Eines Konzepts-Perspektiven für Soziale Arbeit. Edited by Netzwerke im Stadtteil Projekt. Wiesbaden: VS-Verl. für Sozialwissenschaften, pp. 15-35.

Werlen, Benno. 2010. Gesellschaftliche Räumlichkeit 2: Konstruktion Geografischer Wirklichkeiten. Stuttgart: Steiner. 